\title{
Garden policies of the Warsaw housing cooperative: the garden and the right to the city
}

\author{
Magdalena Matysek-Imielińska \\ (Institute of Cultural Studies, University of Wrocław)
}

\begin{abstract}
The article analyzes the project of green spaces to accompany a 1920s residential development in Warsaw. The estate was intended to provide a housing minimum for the poorest inhabitants, as well as educate workers how to live an urban lifestyle. It was presumed that access to greenery, nature, a site of leisure and the smell of flowers cannot be a privilege of the bourgeoisie. Thus, the garden policy proved an emancipatory gesture, an assertion of the right to the city and a means of forging civic mindsets and attitudes. The author asks whether the innocent gardens became workshops in Sennett's understanding, shaping principles and rituals of cooperation, and examines how they helped to promote a new citizen in a new estate.
\end{abstract}

Key words

Cooperative housings, democracy, green space, urban aesthetics

In his Rebel Cities, David Harvey declares at the outset that the "right to the city is, therefore, far more than a right of individual or group access to the resources that the city embodies: it is a right to change and reinvent the city more after our hearts' desire. It is, moreover, a collective rather than an individual right, since reinventing the city inevitably depends upon the exercise of a collective power over the processes of urbanization. The freedom to make and remake ourselves and our cities is, I want to argue, one of the most precious yet most neglected of our human rights" (Harvey 2012, 4). Culturalistic demands to be able to shape oneself in order to collectively create space for a shared life are much more than just ensuring entitlement to joint assets: light, greenery, fresh air, quiet, or even the right to collective consumption. That "far more" is feasible thanks to specific rituals of intersubjective exchange and cooperation, enactment of tacit rules, creation of 
environment from the grassroots, based on social-ecological and educational initiatives.

The interwar years saw Warszawska Spółdzielnia Mieszkaniowa (WSM) (the Warsaw Housing Cooperative) established in the borough of Żoliborz in Warsaw. Its founders, committed cooperativists and socialists, representatives of the Polish radical and secular left, set themselves two goals when designing that communitybased estate; one of those was to ensure the most disadvantaged a housing minimum, while the second objective was rather of an educational-emancipatory kind. The idea was to teach workers how to live the urban way, so that passive residents may become citizens-users of the urban space. The element which the national authorities at the time (whose system, as Barbara Brukalska (1948) wrote, was a capitalist-liberal one) most readily exploited and manipulated to produce social divisions at the most fundamental level was the common good (both the artificial, resulting from productivity, and the natural, i.e., the resources of the land). Thanks to the concept of a cooperative (compared toits post-war, centralist profile, the WSMcan be said to have been a minor cooperative), it became possible to reclaim the common good within the cityscape (fresh air, light, greenery, running water), to reinstate "cultural coexistence," and to reawaken active involvement in the most immediate public space. A system of direct democracy was elaborated there, and, in consequence, a framework of social self-control emerged, using cultural capital and emotional commitment to social affairs. This is because the WSM of Żoliborz witnessed behaviors detached from economic mechanisms of multiplying profit and instead relied on "socialized individualism," joint work (physical labor included) for the benefit of cooperative members (today we would say that a value relocation took placethere to the benefit of its producers).

In July 1934, Adam Próchnik published an article in Życie WSM (Life in WHC), a WSM periodical. His "Polityka ogrodnicza WSM" (Horticultural policy of the WHC) may be interpreted as an ecological, anti-capitalist, and, at the same time, a social manifesto.

If we have left the narrow backstreets, the grey of the horrific tenements, if we have abandoned both the ramshackle dwellings of the suburbs and the morose, tall houses of the inner city to look for a wide space where our household could expand, not only did we strive for light and air for the working people, but also aspired to surround them with the fresh greenness of lawns and the scents of flowers. We have told ourselves-the beauty and charm of this world can no longer be shared by the rich and the affluent only, by the lucky darlings of fortune; it must be attainable to the working man. We have told ourselves-gardens and green spaces must cease to be a privilege. (Próchnik 1934, 1)

In this narrow context, the design of the cooperative membership as multi-faceted that is, both educational (knowledge about nature and the surrounding world, respect for physical labor) and aesthetic ("beauty which soothes the eyes, giving harmony”), as well as economic and ideological. 
A private capitalist chasing after profit from rent would try to exploit every meter to yield interest and revenue, building it all up as wide and high as it can go. Quite unlike a worker's cooperative. Interest does play a role, since it exists in a capitalist system. But this is not the interest of profit, but an extorted tribute to capitalism. That notwithstanding, the cooperative ... acts in accordance with the premises of its social policy. Here, we have vivid proof of the difference in our creative undertakings depending on whether it seeks to gain profit or satisfy social needs. (Próchnik 1934, 1)

While outlining the garden-related agenda of the cooperative, Próchnik enumeratesapart from inner gardens - the external gardens which came into being thanks to the solidary effort of a number of residents. "Finally, one should take into account the institution which develops outside our estate, but remains robustly associated with the latter. What I have in mind are family allotments" (Próchnik 1934, 2).

\section{Greenery - the right to the city and extension of the household}

Let us then examine the garden policy of the WHC, by means of which almost a century ago cooperative members, workers, and inhabitants attempted to reclaim their right to the city. The WHC aspired to provide cheap, modest apartments to those in greatest need. This meant that any rent for the apartments had to be proportional to the wages the workers earned. In consequence, the occupants would obtain very modestly furnished apartments with one and a half rooms, a small kitchen, and a bathroom without a tub or shower. The inconveniences owing to that housing minimum were to be set off by the so-called social facilities: canteens, bathing establishments, and laundries. In line with the idea of a social estate, those collective social sites were extensions of the apartment, erasing the boundary between the private and the public. Speaking of a boundary between the intimate sphere and the sphere of social interaction would be perhaps more pertinent in this case. Hence, architects were convinced that other functions [of the apartment], such as work, childcare, etc. may be gradually relocated from the apartment with advancements in technology and social education. In this sense, the courtyards and green squares would perform social functions as well.

The conditions of leisure will differ depending on age and nature of the group of people. The youngest will play in the gardens, older children-on the school grounds, the adults will enjoy rest in parks and clubs, while the elderly on those courtyards which are not marked as intended for children in the design, in the so-called quiet zones that have been laid out with the physical needs of the elderly taken into consideration. (Syrkus 1975, 301)

Access to parks, greenery, and organized areas of the estate became one of the major objectives in the plans drafted by Barbara Brukalska who, with the splendid social sense of an urban activist, not only designed the housing colonies in Żoliborz but also conducted a critical study of its layout during the war as a member of the 
underground's Office of Architecture and Urban Planning, where she collaborated with, among others, Stanisław Ossowski. Today, her 1948 brochure entitled Zasady spoteczne projektowania osiedli mieszkaniowych (Social principles of designing housing estates) may be seen as a genuine instance of the crossbench spatial practice advocated by Marcus Miessen. Roughly speaking, it would consist in the approach of an architect or urban planner (activist or artist-in short, anyone involved in arranging a space) in which they adopt the standpoint of a researcher who critically analyzes elements that have previously been conceptualized and implemented in the urban space. The practice of urban development is tantamount to research, and the research is tantamount to urban planning practice. This is due to the fact that the design and implementation process yields new knowledge, new ideas, and conceptions. The 'final product' is no longer paramount in light of the processes producingit. Along the way, new knowledge is produced and new ideas and projects can be developed. Rather than a final 'piece' of design, Critical Spatial Practice and its published byproducts present inquiry, documented experiment, a discursively argued thesis toward a 'spatial condition' as Miessen (2007) wrote. In Brukalska's case, this condition resulted in design and social undertakings on a neighborhood scale following a new policy of equal access to common goods and dignified life.

In her independent, modernist practice, Brukalska formulates varied social tenets for architects and urbanists: for instance, a guideline of socialized individualism, utilization of the holiday mode at one place of residence, democratic management, and attractiveness of the estate along withthe possibility of achieving seclusion there. "It is the task of the practitioner designing the estate to lay out a necessary minimum of green networks and areas, which in no case can be diminished" (Brukalska 1948, 17) at the expense of the communication network or structural development. The significance of greenery is fundamental, chiefly as a component of leisure grounds. Social estates and the community workers' estates in the interwar years were to serve as a location where productive forces were recuperated; in other words, they had to ensure comfort, relaxation, and an opportunity for leisure. Hence the guideline concerning the use of the holidaying mode in green surroundings becomes absolutely crucial: "Movement, resting in the open air, mental detachment from the affairs of one's job and household, communing with nature are-from the individual and social viewpoint-the least expensive way to renew one's strength," Brukalska argues $(1948,101)$.

This closely corresponds with Próchnik's garden policy:

The worker's circumstances are such that the greenery must come to him. He needs to be surrounded with greenery. One has to adorn his daily life with verdure and flowers, as he is unable to make a second life for himself. ... Hence the tremendous role of gardens and green areas in a workers' cooperative. They have a triple aim-providing beauty, ensuring health, and supplying knowledge. The knowledge of nature and the surrounding world. Health which comes from the grasses, the green trees, and the colorful, fragrant 
flowers for tired, ailing lungs. Beauty, which brings relief to our eyes. May these eyes of ours find solace in colorful patches and our thought derive harmony from it. (Próchnik $1934,1)$

In this somewhat pompous tone, Próchnik claimed greenery for the workers of Warsaw.

Beyond the political-in a sense-dimension of access to common assets and the possibility of recuperating one's strength, the idea was that the estate, through its social institutions (greenery qualified as such), should make up for the inconvenience of the limited comforts of the modest apartments. The social dimension of the estate was founded on the fact that certain needs may be satisfied in a collective manner by expanding the sphere of interaction.

Thus Brukalska, a modernist architect, looks for even the smallest green plots that may be designated as a site for leisure. For instance, designing the estate's dining hall, she "combines it with a terrace, arcade, or garden, so that during the warm months mealtimes aresimultaneously a time of rest" (Brukalska 1948, 75). Helena Syrkus sees the role of greenery in a similar light, though she enhances it with more ambitious functions. Given that the boundary between the private and the public is abolished in social estates of thiskind, introducing zones of intimacy and interaction instead, green areas become a residential feature to some extent. "A small plaza and a terrace in front of the canteen should be designed as wellso that-weather allowing-meals can be had there. A special, relatively small court would be advisable as well: a kind of 'sitting room' at the estate, with comfortable banks for several-minutes-long meetings and chats. These squares, each serving a different purpose, will be composed into one whole, enclosed by vegetation. This enclosure should be different on each side" (Syrkus 1975, 300).

One has the impression that Syrkus designs plazas-rooms that, just as particular interiors in an apartment, have their designated function; at the same time, it is delineated by verdure and integrated into one entity.

The green areas, the inner courtyards of the estate's colonies and the park, would satisfy the need for some seclusion, but they would also ensure bonding between neighbors and people as such. However, greenery is also an incentive driving a change of custom, encouraging cultural coexistence. "In the green areas, whose surface to resident ratio drops below borderline values ... plants cannot withstand the human pressure. The lawns are trampled down, flowers and shrubs broken, the trees die poisoned by exhaust fumes. Here, countermeasures include increasing cultivation of the inhabitants on the one hand and expanding green areas on the other" (Syrkus 1975, 67).

In Brukalska's conception, they are not only recreational structures or a common good but also a domain of cooperation and "dwelling culture," spaces of relationships and sites of solitude. To Stanisław Ossowski, the parks and the gardens 
at the estate are also "institutions" which become the nexuses of neighborly bonds and social life of the local community (Ossowski 1967, 346).

\section{Greenery - the boundaries of estate identity}

Having examined pre-war Żoliborz, Brukalska began searching for a center and conceptualized the notion of the estate's "core." Its purpose is to create conditions in which the inner life of the estate can be wholly detached from the life of the entire district, in order to ensure a sense of identity with the immediate surroundings, foster attachment, and create a place that people call their own. It should be easily accessible, have a connection to the borough, and should not be shut out from the outside world.

Depicting diverse variants of the alignment of the "estate core," the architect makes allowances for a range of guidelines, but the sense of identity shared by the residents takes precedence. She does not use the term as yet, speaking rather of the estate having to be "coherent" to "single out its life from the entirety of the life of the city" (Brukalska 1948, 116). The "core of the development lies in a park where the life of the whole estate concentrates; it marks the route to such facilities as the reading hall, community center, clubs, as well as a route leading outside, an easily accessible site of leisure, and a venue for meetings of the residents" (Brukalska 1948, 104). In doing so, she polemicizes with Syrkus, who in turn advanced the concept of an "axis of social life," developed a yield of the work in Rakowiec. The "axis of social life" is a belt of greenery traversing several estates, in a way that connects them and establishes a route for pedestrian traffic, at the same time being a transit street. However, for Brukalska, the "axis of social life" does not provide a secluded refuge (with a transit street being a source of noise), nor is it a mass traffic routefor the residents since it does not offer the shortest way to stops.

\section{Teamwork workshops}

The modus operandi of Samodzielne Gospodarstwo Ogrodnicze (the Independent Horticultural Farm) represents an interesting case. It functioned in the borough of Żoliborz since 1932, and its duties included development and management of courtyards and green areas. With the help of the residents and their children the plots under their care were put in order, waterworks were installed, and a horticultural library was established. As time went by, the cultivated area increased considerably. The site was intended as an educational venue, a space of cooperation, and a site of physical work.

In accordance with the WSM's principle of transparency, the horticultural center had its departments (school garden, maintenance of courtyards, as well as foods and trading department), while its functioning was superintended by members 
of the WSM board, a representative of the Robotniczego Towarzystwa Przyjaciól Dzieci (RTPD) (Workers' Society of the Friends of Children) and the head of the horticultural center.

The foods and trading department took care of the sale of flowers and produce to residents of the estate; individual consulting was offered on cultivating gardens and potted plants. Seedlings and cut flowers were also being sold. The year 1936 saw the establishment of the so-called sick plant sanctuary, to which plants and flowers that needed regular tending could be entrusted over the holiday period (in 1938 a total of 659 plants were placed there for "treatment and shelter"). ${ }^{1}$ Flowers on balconies, terraces, courtyards, and squares were tremendously popular. In 1933, Klub Propagandy, Estetyki i Piękna (the Club for Propaganda, Aesthetics, and Beauty) initiated a collection among the residents, whose proceeds would go towards beautifying the courtyards: "Wishing to lend an aesthetic trim to our estate, and to make our cooperative oasis more beautiful, [the Club for Propaganda, Aesthetics, and Beauty] calls upon all residents to make a joint effort. Beginning next week, representatives of the club will be knocking on your doors, citizens of the estate, to bring you a promise of prompt transformation of the courtyards into colorful flowerbeds, and submitting a collection list for your consideration. We believe that no one will refuse even a minor contribution and make our fundraisers leave empty-handed" (O estetykę dziedzińców 1933, 6).

The maintenance department saw regularly to trees, shrubs, lawns, and flowerbeds, as well as to decoration of the shared facilities at the estate (i.e., the community establishments).

In line with the educational aspirations of the Żoliborz undertaking, the garden for children with its animal pens - run as part of the RTPD school-was the most interesting feature. It served the purposes of education and general upbringing, where children could play and spend leisure time as well. A separate committee, comprising ateacher of natural sciences, a representative of the board of the RTPD, and the head of the horticultural center, was in charge of the garden while its organizing committee consisted of an interdisciplinary group of enthusiasts who contributed as volunteers: doctors, architects, natural scientists, agronomists, school teachers, and a number of amateur gardeners from among the residents. In the interwar years, the role of natural sciences were pre-eminent and, in the secular milieu of the WSM, they occupied a particular place in the school curriculum, not only as a science of living things but also as a social science. The school garden was a kind of workshop of systematic and responsible teamwork-teaching coexistence, cooperation, and respect for physical labor. ${ }^{2}$ It was divided into several parts:

See Sprawozdanie $(1939,68)$.

2 Apart from growing plants, children would make garden fixtures (frames, elements of pens and cages for animals) in the adjacent workshops. 
- $360 \mathrm{~m}^{2}$ were occupied by individual patches for older children and shared fields, cultivated jointly by children from the nursery, day-care center as well as firstand second-form pupils.

- in another section, there was the school garden where cereal was grown, mainly for the animals; a number of experimental plots were designated for children's biology groups (rockery, dune plants, pools for plants and aquatic animals, an herb garden).

The produce from the jointly cultivated field washanded over to the school's canteen. Apart from that, children took part in the sale of vegetables, learning the basics of economy. With time, a school zoo and a geography yard were added to the complex.

- the third section of the garden was designated for growing vegetables, flowers and plants needed to decorate the school, seedlings for the garden beds, shrubs, and fruit trees. The work was organized in such a manner that each child was able to participate in various activities (preparing soil for cultivation, raising seedlings, sowing and planting bulbs, tending to perennials, and building frames). The garden workshop was to be used by primary and secondary school children, as well as pupils from schools in the area, thanks to special agreements. Work in the garden was provided for in the adopted curriculum, with two hours per week.

People were also able to sign up for an allotment in the school garden on their own. Children aged 10 and above would thus receive their own patches $\left(3-5 \mathrm{~m}^{2}\right)$. Young gardeners signed a written agreement defining their rights and obligations, the manner of using supplied tools, and expert advice. Also, the agreement stipulated rules of coexistence and cooperation and obliged one to contribute in the shared garden. Children were given their gardening notebooks, in which the course of work and plant growth were recorded. General meetings of all the gardeners were convened from time to time in the garden to discuss comments and desiderata relating to the organization and functioning of the garden. Thus, new solutions were introduced, tools were improved, and streamlining concepts were developed.

Work at the school garden was coordinated by Stanisław Żemis, the natural sciences teacher who, recapitulating his teaching experience in the interwar period in 1958, wrote thus:

Increasing the self-reliance of a child in gardening, from the shared plot of the nursery to the ever-larger personal patch, corresponded with the development and experience of children; at the same time, working in the community patch ensured socialization and fostered coexistential and cooperative capacities. The physical effort, systematicity, and precision that working the garden requires, taught children respect for every kind of human labor, without moralizing about it (Żemis 1958, 17). 
Children tending to animals published an illustrated newsletter describing the life of particular animals and the most recent developments in the garden. The columns entitled "Things done" and "Things we'll do" enjoyed particular interest among the readers (Kuzańska-Obrączkowa 1966, 136).

A recreational-playground area was also provided $\left(800 \mathrm{~m}^{2}\right)$, including a sandbox, volleyball court, a jump track, a bicycle track, and an extensive lawn for all sorts of activities. The playground was quite ingeniously arranged, using bricks and planks, as the creators and architects of the facility wished to avoid the excesses of fancy equipment, which disciplines the children and enforces monotonous and mechanical play. The "building site" playgrounds were intended to promote unconstrained development of constructional forms and free shaping of space. The underlying premise was that it tallied ideally with the needs of children, for whom the very act of arranging their play space, animating objects and construction, are the most compelling activity. In most cases, children do not play in the spaces they have built, but abandon them only to build new ones, playing another game. ${ }^{3}$

The garden was also home to a sports club, a tourism club, and a venue for kayaking workshops run by Igor Newerly, writer, author of Zostało z uczty bogów, and close collaborator of Janusz Korczak.

In the recollections of a Żoliborz child, those "patches" and the animal pens are a vivid memory, an inseparable part of the estate.

The "patches" had been established at the turn of the 1930s at the site where they later built Suzin street, the nursery, the boiler house, the cinema, and further WSMcolonies. With community effort, the soil was cultivated and the hut standing there was put to use. Each WSM child-supervised by an elderly lady, Julia Zubelewicz, and a young gardener named Pawełek-worked at the "patches," sowing and planting various crops and ornamentals. We even had greenhouses where we grew potted plants and seedlings of variousvegetables: tomatoes, cabbage, and kohlrabi. We would pick out the delicate seedlings with tongs and pegs whittled from wood. Paweł was stern: "With tongs like these you can catch a crocodile, not plant out Begonia semperflores," he would say and made us make more subtle tweezers from pieces of wood. We also had an animal corral at the "patches." There were dogs there, hens, geese, ducks, guineafowl, rabbits, guinea pigs and a goat, I guess. For many of our friends who had never seen the countryside, the "patches" were their first opportunity to get to know plants and animals directly, to experience the joy of being around and taking care of them. One would watch how the plants you planted and tended yourself germinated, grew, bloomed, and ripened. Could you ever have anything as magnificent as the first horseradish or pod of peas you had grown yourself? Not

3 A similar approach to spaces intended for children originated in the 1930s with Danish landscape architect, Carl Th. Sørensen. The first "adventure playground" following his concept was created in 1943 in Emdrup, Denmark. Cf. Czałczyńska-Podolska (2010). 
to mention the joy of bringing the first flower from your patch to your mom! (Nowicka $2009,14)^{4}$

Thanks to all those experiences, children in war-time Żoliborz were able to grow vegetables to satisfy the needs of the estate, ensuring it a relative economic autonomy. The hardships of everyday life forced the inhabitants to breed only livestock such as rabbits, hens, and cows, which provided milk indispensable for children and babies. In accordance with the estate's principles, it was distributed among those whose needs were most dire.

The residents took care of the green areas in their surroundings, developing strong local attachments. A 1930 report of the WSM states that "one sees great solicitude for the flowers in the fact that last year, during the lilac-blooming period, the residents spontaneously watched over the latter at nights to protect the blooms from pests" (Sprawozdanie 1930, 100-101). Those who had already acquired the urban manner of habitation also contributed voluntarily to beautifying courtyards, organizing playgrounds and sandboxes for children-even a small pool with a shower was put in place. Annual collections were held to raise funds for the purchase of plants with which the green areas in the courtyards would be adorned. Contests for the best-looking gardens and green squares were held as well, awarding caretakers of particular colonies and residents for the "most flowery balconies." Pertinent news was repeatedly published in Życie WSM, for example:

This year, donations from the residents for the arrangement and maintenance of flowerbeds were in excess of 400 zloty, which enabled the purchase of a substantial quantity of roses (300 shrubs) as well as other flowers and plants. Consequently, the courtyards of the first three colonies have obtained a pleasant aspect, attesting to the cultivation of the residents. ...This year, just as previously, Towarzystwo Przyjaciół Żoliborza [the Society of Friends of Żoliborz] will be organizing a prize competition for the residents of Żoliborz, awarding the best-looking flowerbeds, balconies, and windows. Let us remind you that last year the residents of our estate placed high, therefore we believe that this year's results will not have us fall behind. (Kwietniki 1931, 8)

The horticultural workshops in Żoliborz gave rise to elaborate social rituals, which were acted out publicly (commitments, record books, school classes) rather than behind the scenes. At the same time, they manifested the reciprocal bonds and natural inequality of "master craftsmen," "journeymen," and "apprentices." According to Richard Sennett (2013), the workshop as an institution must function in a manner combining long-term mutual benefits and loyalty with short-term flexibility and openness. Flexibility is indispensable in order to be able to delegate a worker to various undertakings and initiatives (Sennett refers to it as "flexible

4 Incidentally, it is worth mentioning-quite significantly, too-that the recollections were published in 2009 in Życie WSM, in the column "From the pages of history." Thus, the editors of the monthly take care to nurture historical identity in the residents today, and partake in the transfer of knowledge about the "Żoliborz custom," passing on the modes of habitation that boast such noble traditions. 
networking"). Forall intents and purposes, Sennett's workshop means joint work which is founded not only on community but also on "mobile solidarity." After all, acquired skills may be utilized outside the workshop: they may be applied, tested, changed, and modified. The point is in experimenting with the capabilities one already possesses, be it skills relating to physical work, cultural competence, or social bonds. Flexible cooperation is a skill which, though acquired in the workshop, is developed later on one's own and conveyed to the local community, one's home, milieu, and into the public sphere most of all, so that one may become a citizen who consciously shapes social relationships. Thus, what the Żoliborz activists had in mind was "a new facet of a man, transcending the workshop to become present in the apartment, the house, and the estate" (Szwalbe 1962, 17), the formation of a comprehensively developed, socialized, and sensitive citizen, a user of the city who, by virtue of collective action, will justly claim the right to change public space and reinvent the city as they see fit-to build a city that is alive and functions thanks to grassroots initiatives, offering open space that ensures equal access to shared assets, as opposed to a city construed as urbanized space in which taking advantage of municipal institutions is a privilege. Addressing the educationalemancipatory aspirations of the Żoliborz agenda, Maria Swodobowa outlines its chief goals: "the platform slogan of Żoliborska Rzeczpospolita Spółdzielcza (the Żoliborz Cooperative Republic) was 'A New Man in a New Estate.' ...The new individual meant a thoroughly developed one, capable of deriving joy from the beauty of nature, art, science, and above all from cooperation and fraternal coexistence with others" (Swobodowa 1963, 95).

The projects aimed at filling the estate with greenery and the Żoliborz gardens were some of the numerous elements of that comprehensive educational experiment at a housing estate.

\section{Family allotment gardens}

Allotment gardens for numerous families were organized on the plots neighboringa place then named Buraków. Naturally, a dedicated self-governing body was established as well, with Edward Osóbka (a resident of the Żoliborz estate) elected as its head. On the initiative of the lessees, a mutual help section was created, chiefly to facilitate an exchange of plants between them and to help one another in putting up frames. The lease fee for an allotment of $300 \mathrm{~m}^{2}$ was 3.50 złoty, with an additional 2 złoty registration fee. ${ }^{5}$ Although the institution was external to the WSM, residents of the estate lent it a community-like, social character. Thus, the family allotments became a part of the WSM's garden policy.

5 See "Kolonia ogródków rodzinnych na Żoliborzu" $(1933,4)$. 
As mentioned before, the WSM wanted to build apartments for those in in greatest need, the poorest workers' families, who made a living with the work of their own hands. Concerned with comfort and the housing minimum, the architects of Zespół "U" designed a complex of cheap terraced houses as well. Even though it was never implemented, the economic premises of the undertaking deserve to be considered, as the architects in question (J. Chmielewski, St. Filipkowski, Br. Kulesza, H. Kurkiewicz, L. Tomaszewski, J. Żakowski) assumed that a garden adjoining the house would have been an indispensable element of a dwelling intended for a family of $4-5$ people, given that it would have ensured the most disadvantaged relative economic independence. Drawing on the studies of a Dr Gertrude Laupheimer (Laupheimer, 1931), they determined that in order to obtain produce for a family of that size approximately $300 \mathrm{~m}^{2}$ should be allotted for a vegetable garden and ca. $450-500 \mathrm{~m}^{2}$ for a fruit garden. Regardless of the latter, $500 \mathrm{~m}^{2}$ of soil should be available for a yield of around $600-900 \mathrm{~kg}$ of potatoes. Hence, a plot approaching $1000 \mathrm{~m}^{2}$ would have guaranteed self-sufficiency in terms of produce. At the same time, the creators of the design provided for discretionary use of the allotments, whereby individual residents would have been able to cede their allotment in favor of other residents or the cooperative. The latter would thus have utilized the plot for a cooperative garden farm, a sports field for children, or converted it to a green area. ${ }^{6}$

\section{Gardens of the estate, or DIY}

According to Chris Carlsson, the contemporary principle of do it yourself, developed in grassroots production and services which are not geared towards profit but towards reclaiming a sense of labor and nurturing bonds within a community, yields a different lifestyle, different modes of coexistence, new environments (Carlsson 2008, 52). Such models are implemented today by diverse urban movements that adopt autonomous strategies in urban agriculture and organize workshops as part of which people jointly engage in cultivation within a city. In Warsaw, Pracownia Dóbr Wspólnych (the Commons Lab) runs Szkoła Ogrodników Miejskich (Urban Gardening School, an urban activity based on the knowledge of "how to grow plants in the city: vegetables, herbs, flowers. How to create gardens, but there is also the knowledge of doing it together, as a community-how to create the urban environment from the grassroots, locally, in collaboration with others," says Maciej Łebkowski, one of the founders of the undertaking (Miasto2077 2016). "We would like to enhance the process of changing the city, developing projects of citywide scope with public-social components. These may be roof gardens or educational

6 See Zespół “U”(1932). 
gardens adjoining nursery schools," adds Michał Augustyn from Pracownia Dóbr Wspólnych.

The "nowtopia" suggested by Carlsson is a kind of city-centric anti-capitalism. ${ }^{7}$ It is an autonomous zone where one of the fundaments is socially useful labor performed outside market economy and profit-driven logic: work undertaken in one's free time to reify the ideals of community life. Carlsson sees work of thiskind as a tool in the struggle against commodification of the basic forms of everyday activities. According to the author, creating "nowtopia" is not a rebellion of the working classes but a manifestation of dissent to labor that is alienating and pointless. However, Carlsson has no revolutionary aspirations that would seek to confront and clash with the system. "Nowtopias" represent something akin to temporary autonomous zones, local and short-lived initiatives which open up space for a life in dignified conditions based on direct democracy and principles of autonomy. Thus, developing well-thought-out strategies as well as minor, ephemeral tactics of resistance link diverse "social centers" into a network. These 'autonomous zones,' through the process of occupying and opening up space that would otherwise be private and closed, facilitate the creation of life 'held in common.' Employing the practice of self-management and principles of autonomy, participants aim to create an example of an alternative to contemporary capitalist society. ...Social centres make private space 'common' and are run on non-profit values. They act as both an ideological and material form of opposition to capitalist logic and its enclosures (Pusey 2010, 176-198).

Carlsson's "nowtopia" may be readily employed to analyze the Żoliborz project of a social estate, which consequently proves an interesting idea-requiring an update, perhaps-for a new urban mode of living based on the increasingly often redeemed concept of the cooperative and collaboration, where the city is a domain of collective and organized action.

It may also be added that the introduction of agricultural zones of self-governed and sovereign labor is seen beyond the cityscape as well. This is also a path taken by contemporary peasants and small farmers who, facing capitalist industry, began to wage a "food war" in the name of "food sovereignty."

This is why the international organization Via Campesina strives to propagate communal and collective forms of ownership, which can promote a sense of ecological responsibility and facilitate equal distribution of produce. The way to social and economic restructuring leads through self-government, diversity, and cooperation. Indeed, one finds movements of repeasantization, as entrepreneurial farmers abandon capitalist farming and increasing numbers of urbanites take up

7 The main inspiration here originates with the movement that began in the US in the 1960 and continues until today. Its adherents advocate independent production and repairs of various appliances and furnishings, redevelopment of disused facilities and vacant spaces, establishing gardens, etc. Whole Earth Catalog magazine may be considered a forum of that movement. See Carlsson (2008, 47-48). 
small-scale agriculture. One might even consider the possibility that, as van der Ploeg puts it, "the emergence of urban agriculture in many parts of the world signals the emergence of new numbers of (part-time) peasants and a simultaneous spatial shift of the peasantry from the countryside toward the big metropolises of the world" (Bello 2009, 148).

Hence, one may ask whether the WSM, with its idea for Gospodarstwo Ogrodnicze (Horticultural Farm) and the estate gardens could not become an inspiration and an example of efficient (and empowering) functioning at the level of a "base" framework?

The multi-dimensional concern for green areas, parks, alleys bordered with verdure, and above all the estate's cultivated gardens may be treated as a manifestation of entitlement to common assets, a gesture rooted in workers' and cooperative's ethos that asserts that access to greenery cannot be a privilege of a narrow social stratum, as Próchnik put it. It may also be perceived as a local form of organizing estate workshops or laboratories which teach not only garden craft but also instill the attitude of a responsible citizen-an inhabitant of a city.

\section{Conclusion}

I have suggested that the Żoliborz estate of the Warsaw Housing Cooperativein particular its garden-related aspects - can be analyzed while setting out from Adam Próchnik's postulation of claiming right to the city, of gaining access to green areas that constitute shared natural assets. This fundamental right was exercised by the cooperative's activists, architects, and residents themselves in the bottomup mode, independently, cooperatively, while developing rules of collaboration that Carlsson would have defined as do it yourself in the autonomous zone of labor reclamation. All the analyzed means of getting the residents involved and kinds of activist-driven undertakings based on principles of collective space-making tally with Sennett's notions of workshop, a paradigmatic figure of being together, cooperation, and craftsmanship that mold a new person: one who welcomes the social creation of rules and rituals of team-based action, who is sensitive to various aspects of labor and aware of one's responsibility for the latter. It was at Ośrodek Ogrodniczy (the Horticultural Center) that the people of Żoliborz forged that very model.

As for the architectural designs and critical studies by Helena Syrkus and Barbara Brukalska, I have approached them as instances of modernist critical spatial practice (in line with Marcus Miessen). These committed architects would not only design workers' estates, but also demonstrated great sensitivity to workers' opportunities to exercise their rights to dignified living conditions in the city. With extraordinary creativity and critical acumen, they analyzed the functioning of existing spaces, treating themas components of the residents' existential circumstances. 


\section{The greenery at the estate was more than just an extension of an apartment; it man- ifested the civic right to a common asset.}

\section{References:}

Bello, Walden. 2009. Food Wars. London: Verso.

Brukalska, Barbara. 1948. Zasady spoleczne projektowania osiedli mieszkaniowych [Social principles of designing housing estates]. Warsaw: Wydawnictwo Ministerstwa Odbudowy.

Carlsson, Chris. 2008. Nowtopia. How Pirate Programmers, Outlaw Bicyclists, and Vacant-Lot Gardeners Are Inventing the Future Today! Edinburgh: AK Press.

Czałczyńska-Podolska, Magdalena. 2010. "Ewolucja Placu zabaw. Koncepcja dla dzieci w Europie i Stanach Zjednoczonych" [Evolution of the playground: An idea for children in Europe and the United States]. Przestrzeń i forma13, 73-88.

Harvey, David. 2012. Rebel Cities: From the Right to the City to the Urban Revolution. London: Verso.

"Kolonia ogródków rodzinnych na Żoliborzu" [The colony of family gardens in Żoliborz]. 1933. Życie WSM, October.

Kuzańska-Obrączkowa, Maria. 1966. Koncepcje wychowawcze Robotniczego Towarzystwa Przyjaciót Dzieci 1919-1939. Analiza założeń i funkcjonowania placówek [Educational guidelines of Workers' Society of the Friends of Children 1919-1939: An analysis of the premises and functioning of establishments]. Wrocław: Zakł. Nar. im. Ossolińskich.

"Kwietniki" [Flowerbeds]. 1931. Życie WSM, June, 8

Laupheimer, Gertruda. 1931. Gartenstadt XI. Berlin.

Miasto2077. 2016. "Szkoła miejskich ogrodników rusza w Warszawie" [A school of urban gardening commences in Warsaw]. May 6. http://www.miasto2077.pl/szkola-miejskich-ogrodnikow-ruszaw-warszawie.

Miessen, Marcus. 2007. The Violence of Participation. Berlin: Sternberg Press.

Syrkus, Helena. 1975. Ku idei osiedla spotecznego 1925-1975 [Towards the idea of a social estate 1925-1975]. Warsaw: PWN.

Nowicka, Maria. 2009. "WSM—RTPD—Szklane Domy" [WSM—RTPD—glass houses]. Życie WSM, September.

"O estetykę dziedzińców osiedla" ["On the aesthetics of estate yards"]. Życie WSM, March.

Ossowski, Stanisław. 1967. Dzieła, Tom III, Z zagadnień psychologii społecznej [Collected works, volume III, issues insocial psychology]. Warsaw: PWN.

Próchnik, Adam. 1934. "Polityka ogrodnicza WSM" [Horticultural policy of the WSM]. Życie WSM, July.

Pusey, Andre. 2010. "Social Centres and the New Cooperativism of the Common." A Journal of Radical Theory, Culture, and Action 4(1), 176-98.

Sennett, Richard. 2013. Razem. Rytualy, zalety i zasady wspófpracy[Together: The Rituals, Pleasures, and Politics of Cooperation]. Translated by Jan Dzierzgowski. Warsaw: Warszawskie Wydawnictwo Literackie MUZA SA. [Original edition: Together: The Rituals, Pleasures, and Politics of Cooperation, London: Penguin Books, 2013] 


\section{Magdalena Matysek-Imielińska}

Sprawozdanie WSM [WSM Report]. 1930. Warsaw.

Sprawozdanie z dziatalności WSM za rok 1938 [WSM Report for 1938]. 1939. Warsaw

Swobodowa, Maria. 1963. "Ośrodek szkolno-wychowawczy na Żoliborzu" [Educational establishment in Żoliborz]. In Eksperymenty pedagogiczne w Polsce w latach 1900 — 1939 [Pedagogical experiments in Poland in 1900-1939], edited byBolesław Suchodolski, 94-111. Wrocław: Zakł. Nar. im. Ossolińskich.

Szwalbe, Stanisław. 1962. "Sylwetki" ["Profiles"]. Życie osiedli WSM.

Zespół "U."1932. "Dom—Osiedle—Mieszkanie" ["House—estate—apartment"]. Zespót "U," November.

Żemis, Stanisław. 1958. "Ogród szkolny RTPD na Żoliborzu jako koncepcja metodyczno-wychowawcza" [RTPD school garden in Żoliborz as a methodological and educational idea]. Życie Szkoły $12,17-20$. 